\title{
PELATIHAN PLIOMETRIK DEPTH JUMP LEBIH MENINGKATKAN DAYA LEDAK OTOT TUNGKAI DARIPADA PELATIHAN PLIOMETRIK BOX JUMP SISWA PESERTA EKSTRAKURIKULER BOLA VOLI SMK NEGERI 1 PETANG
}

\author{
I Putu Prisa Jaya ${ }^{1}$, Ketut Tirtayasa ${ }^{2}$, I Made Muliarta ${ }^{3}$ \\ Luh Made Indah Sri Handari Adiputra ${ }^{4}$, Susy Purnawati ${ }^{5}$, I Putu Adiartha Griadhi ${ }^{6}$ \\ ${ }^{1}$ Program Studi Magister Fisiologi Keolahragaan,Universitas Udayana \\ 2,3,4,5,6 Bagian Ilmu Faal Fakultas Kedokteran, Universitas Udayana, Denpasar Bali
}

\begin{abstract}
ABSTRAK
Olahraga bola voli menggunakan teknik dasar yang memfungsikan kelompok otototot besar terutama otot tungkai dalam memfasilitasi gerakan saat melakukan loncatan. Daya ledak didefinisikan sebagai kemampuan otot dalam mengerahkan kekuatan yang maksimal serta dalam waktu cepat. Daya ledak otot tungkai merupakan komponen penting dalam melakukan gerakan smash, passing dan block dalam cabang olahraga bola voli. Komponen tersebut diperlukan dalam peningkatan pelatihan pliometrik. Pelatihan pliometrik depth jump dan pelatihan pliometrik box jump menggunakan prinsip beban progresif dimana frekuensi pelatihan yang digunakan sebanyak tiga kali seminggu dalam kurun waktu enam minggu. Tujuan dari penelitian ini yaitu untuk membandingkan pelatihan mana yang lebih mampu meningkatkan daya ledak otot tungkai. Metode penelitian yang digunakan yaitu metode eksperimental dengan rancangan penelitian menggunakan randomized pre test and post test group design yang dilaksanakan selama enam minggu dengan frekuensi pelatihan sebanyak tiga kali dalam seminggu. Sampel yang digunakan sebanyak 32 orang yang kemudian dibagi menjadi dua kelompok pelatiahan. Pelatihan pliometrik depth jump diberikan pada kelompok I sedangkan pelatihan pliometrik box jump diberikan pada kelompok II. Pengukuran daya ledak otot tungkai yang dilakukan pada masing-masing kelompok menggunakan jump DF yang diukur pada saat sebelum dan sesudah pelatihan. Hasil uji statistik menunjukkan daya ledak otot tungkai pada Kelompok I sebelum pelatihan 42,25 $\pm 3,92 \mathrm{~cm}$ dan setelah pelatihan $51,81 \pm 4,14 \mathrm{~cm}(\mathrm{p}<0,05)$. Pada Kelompok II sebelum pelatihan 40,25 $\pm 5,14 \mathrm{~cm}$ dan setelah pelatihan 45,25 $\pm 5,07 \mathrm{~cm}(\mathrm{p}<0,05)$. Pelatihan pada Kelompok I memiliki peningkatan hasil daya ledak otot tungkai lebih besar daripada pelatihan pada Kelompok II ( $\mathrm{p}<0,05)$. Sehingga dapat disimpulkan bahwa pelatihan pliometrik deph jump lebih mampu meningkatkan daya ledak otot tungkai dibandingkan dengan pelatihan pliometrik box jump pada siswa peserta ekstrakurikuler bola voli di SMK Negeri 1 Petang.
\end{abstract}

Kata kunci: pelatihan pliometrik box jump dan depth jump,, daya ledak otot tungkai, olahraga bola voli. 


\title{
PLYOMETRICS DEPTH JUMP TRAINING IS MORE MAXIMIZE THE POWER LEG MUSCLE PLYOMETRICS THAN BOX JUMP TRAINING AMONG STUDENTS OF VOLLEYBALL EXTRACURRICULAR AT SMK NEGERI 1 PETANG
}

\begin{abstract}
The basic techniques of volleyball used to use muscular group in our body, especially the leg's muscles that is facilitating the springboard movement. Explosive power is the ability of muscles to exert maximum force in a very quick time. Leg muscle explosive power is one of the essential components required in the sport of volleyball particular in the motion of smash, passing and blocking hat needs to be improved by training plyometrics. The training that were conducted during this research are the plyometric depth jump and plyometric box jump training using the principle of progressive load with 3 times frequencies a week within 6 weeks. The aim of this study is to compare the explosive power of training leg muscle. This study use a randomized experimental design with pre test and post test group design for six weeks with 3 times frequencies a week. The sample's numbers is 32 participants that was divided into two groups. The first group was given training in plyometrics depth jump and the second group was given training plyometrics box jump. The explosive power of leg muscle is measured by using a jump DF which measured before and after training for each groups. The result of this research is shown before training in group I is $42.25 \pm 3.92 \mathrm{~cm}$ and $51.81 \pm 4.41 \mathrm{~cm}$ after training ( $\mathrm{p}<0.05)$. While, in group II the mean shows $40.25 \pm 5.14 \mathrm{~cm}$ before training and $45.25 \pm 5.07 \mathrm{~cm}$ after training $(\mathrm{p}<0.05)$. Training in group I can increase explosive power leg muscle than group II $(\mathrm{p}<0.05)$. Based on the result, it is concluded that the plyometric depth jump training is more better than the plyometric box jump training in increasing explosive power leg muscle for the students of volley ball extracurricular at SMK Negeri 1 Petang.
\end{abstract}

Keywords: plyometrics depth jump training and box jump, explosive power leg muscle, sports volleyball. 


\section{PENDAHULUN}

Upaya-upaya yang dilakukan untuk meningkatkan kebugaran dan prestasi olehraga adalah pelatihan yang sistematis dan terprogram. Pelatihan merupakan suatu proses yang dilakukan untuk memperbaiki serta meningkatkan fungsi dari sistem organ tubuh agar mampu berfungsi dengan optimal saat melakukan aktivitas khususnya olahraga. ${ }^{1}$

Pelatihan yang diberikan dapat dipengaruhi oleh teknik, kondisi fisik, mental, taktik, lingkungan serta sarana dan prasarana yang merupakan factor-faktor yang penting untuk diperhatiakan untuk mencapai prestasi puncak dalam olahraga. ${ }^{1}$

Kondisi fisik merupakan unsur terpenting yang diperlukan dalam pelatihan, dimana dilakukannya latihan fisik dapat meningkatkan fungsi dari sistem organ tubuh sehingga mampu mempengaruhi penampilan dalam beraktivitas. ${ }^{1}$ Terdapat sepuluh komponen biomotorik dalam tingkat kemampuan fisik diantaranya: kekuatan, daya ledak, keseimbangan, kecepatan, ketepatan, daya tahan, koordinasi, kelentukan, serta waktu reaksi kelincahan. ${ }^{2}$

Berdasarkan hasil observasi di SMK

Negeri 1 Petang diperoleh data awal yang menunjukkan rendahnya hasil belajar bola voli siswa dan berdampak pada Pekan Olahraga Pelajar (PORJAR) Kabupaten Badung tahun 2014, kontingen SMK Negeri 1 Petang pada cabang bola voli kalah dalam babak penyisihan dan pada tahun 2015 SMK Negeri 1 Petang tidak mengirimkan atlet pada cabang bola voli. Hal tersebut menunjukkan tidak adanya peningkatan prestasi pada cabang bola voli di SMK Negeri 1 Petang, kemungkinan disebabkan oleh berbagai faktor seperti aspek kondisi fisik, pelatihan-pelatihan yang diberikan dan teknik setiap pemain sehingga masih mungkin untuk ditingkatkan.
Sama seperti olahraga lainnya, permainan olahraga bola voli mengharuskan pemainnya untuk menguasai teknik dasar terlebih dahulu sebagai acuan untuk dapat bermain voli secara efektif. Teknik tersebut meliputi service, passing, block dan yang terpenting adalah smash. ${ }^{3}$ Kalah atau menang dalam permainan olahraga bola voli bergantung pada baik dan tidaknya kemampuan teknik dasar yang dimiliki pemain. Dalam permainan olahraga bola voli teknik smash merupakan sebuah pukulan yang digunakan sebagai suatu serangan dalam mematikan bola dimana teknik smash tersebut bertujuan untuk memperoleh point. Menggunakan gerakan smash seorang pemain dituntut untuk memiliki kontrol atau kendali terhadap ketepatan serta tembakan, oleh karenanya untuk memudahkan pemain dalam menempatkan bola, pemain tersebut haruslah ditunjang dengan kemampuan teknik meloncat yang baik sehingga dapat memudahkan dalam mematikan bola dengan smash dan sekaligus memperoleh point.

Dalam permainan bola voli kemampuan melompat sangat berhubungan dengan daya ledak otot tungkai. Untuk memudahkan penempatan bola didaerah kosong lawan pada saat mendapatkan peluang mematikan bola harus memiliki lompatan yang baik. ${ }^{4}$ Daya ledak adalah bagian tubuh atau kemampuan tubuh yang berkontraksi dengan sangat cepat untuk mengatasi tahanan yang terjadi secara mendadak atau tiba-tiba dengan cepat, dimana tubuh terdorong kearah depan (horizontal) atau ke atas (vertikal) baik dengan cara melompat (menapak dengan satu kaki) atau meloncat (menapak dengan kedua kaki), dengan menggerakkan otot maksimal. ${ }^{1}$

Pelatihan yang baik hendaknya dilakukan sesuai dengan gerak berolahraga yang sesungguhnya. ${ }^{5}$ Salah satu usaha dalam 
mengembangkan daya ledak eksplosif adalah dengan melakukan pelatihan pliometrik dengan kecepatan kontraksi otot dan kekuatan yang dapat mempengaruhi kontraksi otot secara langsung. Pelatihan pliometrik merupakan respon dari pembebanan dinamik yang mempunyai cirri kusus regangan kontraksi otot yang cepat dan kuat dari otot terkait. ${ }^{6}$

Permainan bola voli tergantung pada baik tidaknya kemampuan teknik dasar yang dimiliki setiap pemain. Smash merupakan teknik dasar yang digunakan menyerang lawan untuk memperoleh point. Gerakan smash dilakukan dengan melakukan lompatan yang tinggi dan memukul bola diatas net sekeras mungkin ke daerah kosong pertahan lawan. Saat melakukan gerakan smash pemain dituntut untuk memiliki oleh karenanya untuk memudahkan pemain dalam menempatkan bola, pemain tersebut haruslah ditunjang dengan kemampuan teknik meloncat yang baik sehingga dapat memudahkan dalam mematikan bola dengan smash dan sekaligus memperoleh point

Dengan kekuatan dan daya ledak otot yang baik maka sangat memungkinkan didapat peningkatan tinggi lompatan smash pada atlet bola voli. Melihat pentingnya pelatihan pliometrik untuk meningkatkan daya ledak harus ditunjang dengan penerapan metode dan prinsip-prinsip pelatihan. Pelatihan yang baik dan tepat dapat meningkatkan kemampuan komponen biomotorik yang dominan diperlukan dalam permainan bola voli, sehingga seluruh komponen biomotorik tersebut dapat saling menunjang untuk meningkatkan vertical jump dan smash dalam permainan bola voli.

\section{METODE PENELITIAN}

\section{Rancangan Penelitian}

$\begin{array}{ccc}\text { Rancangan } & \text { penelitian } & \text { yang } \\ \text { digunakan dalam penelitian ini yaitu }\end{array}$

menggunakan The Randomized Pre and Post Test Group Design membandingkan dua Kelompok perlakuan. Kelompok I diberikan pelatihan pliometrik depth jump dan Kelompok II diberikan pelatihan pliometrik box jump.

\section{Waktu dan Lokasi Penelitian}

Penelitian dilaksanakan bertempat pada lapangan olahraga bola voli dan aula SMK Negeri 1 Petang dan waktu penelitian dilaksanakan dari tanggal 12 Desember 2016 samapai dengan tanggal 20 Januari 2017 dengan frekuensi tiga kali seminggu.

\section{Populasi dan Sampel}

Populasi yang digunakan pada penelitian ini yaitu seluruh siswa yang memilih ekstra kurikuler bola voli di SMK Negeri 1 Petang. Sampel penelitian ini yaitu siswa yang mengikuti ekstra kurikuler bola voli di SMK Negeri 1 Petang memenuhi kriteria inklusi dan eksklusi.

\section{Prosedur Penelitian}

Prosedur penelitian ini dibagi menjadi tiga tahapan yaitu: tahap persiapan, tahap pemilihan sampel dan tahap pelaksanaan penelitian. Tahap persiapan: Mempersiapkan surat ijin penelitian yang ditujukan kepada kepala sekolah SMK Negeri 1 Petang, Menyiapkan blangko-blangko dan alat-alat tulis untuk keperluan penelitian dan Menyampaikan informasi kepada siswa tentang tahapan-tahapan penelitian.

Tahap pemilihan sampel: Sampel dipilih secara acak sederhana dari jumlah seluruh siswa yang mengikuti ekstra kurikuler bola voli di SMK Negeri 1 Petang yang dipilih berdasarkan kriteria inklusi dan eksklusi sesuai dengan teknik pemilihan sampel.

Tahap penelitian: Tes awal (pre test) dilakukan sebelum pelatihan daya ledak otot tungkai diukur dengan tes vertical jump menggunakan Jump DF , Kelompok I diberikan pelatihan pliometrik depth jump 
dan Kelompok II diberikan pelatihan pliometrik box jump dilakukan selama 3 kali pelatihan setiap minggu selama 6 minggu. Sebelum pelatihan dilakukan pemanasan selama sepuluh sampai limabelas menit. Pelatihan ini menggunakan prinsip pelatihan dengan beban progresif, tinggi box yang digunakan dihitung dari rerata tes awal (pre tes) vertical jump dilakukan selama tiga minggu. Kemudian dilakukan tes evaluasi untuk peningkatan tinggi box yang digunakan dihitung dari rerata tes evaluasi, pelatihan dilakukan selama tiga minggu. Setelah pelatihan selama enam minggu dilakukan tes akhir. Tes akhir (post test) dilakukan setelah pelatihan diukur dengan tes vertical jump menggunakan Jump DF.

\section{Analisis Data}

Data yang diperoleh sebelum dan sesudah pelatihan dianalisis dengan menggunakan langkah-langkah sebagai berikut: (a) Analisis Deskriptif Untuk menganalisis data subjek seperti tinggi badan, berat badan yang datanya telah diambil, (b) Analisis Komparasi: (1) Uji normalitas data dalam penelitian ini menggunakan saphiro wilk test, yang dimaksudkan untuk mengetahui distrbusi data pada masing-masing kelompok perlakuan. Baik sebelum atau sesudah penelitian. (2) Uji homogenitas menggunakan levene test dimaksud untuk mengetahui batas kemaknaan atau tingkat kepercayaan dengan $\alpha=0,05$ serta variasi data. (3) Uji komparasi yang dilakukan pada kedua kelompok antara sebelum dan sesudah diberikan pelatihan dengan menggunakan uji t-paired (berpasangan) yang dimaksud untuk menganalisis rerata peningkatan atau perubahan setelah pelatihan pada kelompok pelatihan pliometrik depth jump dan kelompok pelatihan pliometrik box jump. Uji $t$ independent digunakan untuk melihat perbedaan efek rerata dari daya ledak pada sebelum maupun sesudah diberikan pelatihan antara Kelompok I dan II. Batas kemaknaan atau tingkat kepercayaan yang digunakan adalah $\alpha=0,05$. Apabila nilai $\alpha<$ 0,05 memiliki arti bahwa hipotesis penelitian diterima atau memiliki perbedaan yang signifikan, sedangkan apabila nilai $\alpha>$ 0,05 memiliki arti hipotesis tersebut ditolak atau tidak memiliki perbedaan yang signifikan.

\section{HASIL PENELITIAN}

\section{Karakteristik Subjek Penelitian}

Karakteristik subjek dalam penelitian ini meliputi: berat badan, tinggi badan, panjang tungkai, IMT, panjang kaki, kekuatan otot tungkai dan kebugaran fisik. Hasil deskripsi dari karakteristik subjek penelitian dapat dilihat dalam table 1

Tabel 1

Karakteristik Subjek Penelitian

\begin{tabular}{lccc}
\hline \multirow{2}{*}{ Karakteristik } & Kelompok I & $\begin{array}{c}\text { Kelompok II } \\
\text { Pelatihan Pliometrik } \\
\text { Depth Jump }\end{array}$ & $\begin{array}{c}\text { Pelatihan Pliometrik } \\
\text { Box Jump }\end{array}$ \\
\cline { 2 - 4 } & $\mathrm{n}$ & Rerata \pm SB & Rerata \pm SB \\
\hline Tinggi Badan $(\mathrm{cm})$ & 16 & $167,31 \pm 6,96$ & $163,19 \pm 5,72$ \\
Berat Badan $(\mathrm{kg})$ & 16 & $60,00 \pm 6,96$ & $56,19 \pm 6,35$ \\
IMT $\left(\mathrm{kg} / \mathrm{m}^{2}\right)$ & 16 & $21,38 \pm 1,36$ & $20,99 \pm 1,82$ \\
Panjang Tungkai $(\mathrm{cm})$ & 16 & $92,74 \pm 5,76$ & $91,60 \pm 4,46$ \\
Panjang Kaki $(\mathrm{cm})$ & 16 & $25,26 \pm 0,94$ & $25,15 \pm 0,87$ \\
Kekuatan Otot Tungkai $(\mathrm{kg})$ & 16 & $113,19 \pm 33,10$ & $112,38 \pm 28,80$
\end{tabular}


Kebugaran Fisik (Waktu

16

$11,10 \pm 1,06$

$11,59 \pm 1,22$

Tempuh lari 2,4 km)

\section{Karakteristik Lingkungan Penelitian}

Suhu udara pada lingkungan penelitian digunakan dalam satuan ${ }^{0} \mathrm{C}$, sedangkan kelembaban relatif pada lingkungan penelitian disesuaikan dengan
Tabel psycometric chart dalam \%, hasil dari pengukuran suhu di lapangan bola voli SMK Negeri 1 Petang selama pelatihan. Hasil Deskripsi Karakteristik Lingkungan Penelitian dapat dilihat pada tabel 2.

Tabel 2

Hasil Pengukuran Suhu Lingkungan Penelitian

\begin{tabular}{ccccc}
\hline Keadaan Lingkungan & $\mathrm{n}$ & Rerata \pm SB & Minimal & Maksimal \\
\hline Suhu Kering $\left({ }^{0} \mathrm{C}\right)$ & 18 & $28,54 \pm 0,77$ & 27,1 & 30 \\
Suhu Basah $\left({ }^{0} \mathrm{C}\right)$ & 18 & $25,38 \pm 0,47$ & 24,7 & 26 \\
Kelembaban $(\%)$ & 18 & $70,06 \pm 11,28$ & 65,0 & 78 \\
\hline
\end{tabular}

\section{Uji Normalitas dan Homogenitas}

Uji normalitas data menggunakan
Saphiro Wilk Test digunakan untuk mengetahui distribusi sampel penelitian,

Tabel 3

Hasil Uji Normalitas dan Homogenitas Data Hasil Daya Ledak Otot Tungkai Sebelum dan

Sesudah Pelatihan

\begin{tabular}{cccc}
\hline \multirow{2}{*}{ Hasil Analisis } & (p) Uji Normalitas (Shapiro Wilk Test) & \multirow{2}{*}{$\begin{array}{c}\text { (p) Uji Homogenitas } \\
\text { (Levene Test) }\end{array}$} \\
\cline { 2 - 3 } & Kelompok I & Kelompok II & 0,235 \\
Sebelum Pelatihan & 0,436 & 0,545 & 0,346 \\
Sesudah Pelatihan & 0,543 & 0,852 & \\
\hline
\end{tabular}

Hasil tes pada kedua kelompok dimana hasil daya ledak otot tungkai baik sebelum dan sesudah diberikan pelatihan berdasarkan hasil analisis data yaitu dengan uji normalitas dan homogenitas data didapat memiliki nilai ( $\mathrm{p}>0,05)$, sehingga data daya ledak otot tungkai sebelum maupun sesudah diberikan pelatihan memiliki distribusi normal dan varian yang homogen.

\section{Hasil Uji Beda Daya Ledak Otot Tungkai Antar Kelompok}

Membandingkan hasil rerata dari daya ledak otot tungkai sebelum maupun sesudah diberikan pelatihan digunakan analisis uji beda, dimana pada Kelompok I dengan pelatihan pliometrik depth jump sedangkan pada Kelompok II diberikan pelatihan pliometrik box jump yang kemudian hasil analisis kemaknaan digunakan uji t-independent (tidak berpasangan).

Tabel 4

Uji Beda Rerata Hasil Daya Ledak Otot Tungkai Antar Kelompok Pelatihan

\begin{tabular}{|c|c|c|c|c|c|}
\hline Hasil Daya & & Kelompok I & Kelompok II & & \\
\hline $\begin{array}{l}\text { Ledak Otot } \\
\text { Tungkai }\end{array}$ & $\mathrm{n}$ & $\begin{array}{c}\text { PelatihanPliometrik } \\
\text { Depth Jump }\end{array}$ & $\begin{array}{c}\text { Pelatihan Pliometrik } \\
\text { Box Jump }\end{array}$ & $\mathrm{t}$ & $\mathrm{p}$ \\
\hline
\end{tabular}




\begin{tabular}{lccccc}
\hline \multicolumn{5}{c}{ Rerata \pm SB $(\mathrm{cm})$} & Rerata \pm SB $(\mathrm{cm})$ \\
\hline $\begin{array}{l}\text { Sebelum } \\
\text { pelatihan }\end{array}$ & 16 & $42,25 \pm 3,94$ & $40,25 \pm 5,14$ & 1,158 & 0,256 \\
$\begin{array}{l}\text { Sesudah } \\
\text { pelatihan }\end{array}$ & 16 & $51,81 \pm 4,15$ & $45,25 \pm 5,07$ & 4,008 & 0,000 \\
\hline
\end{tabular}

Berdasarkan hasil uji beda rerata antara kedua kelompok tersebut dimana pada hasil sebelum diberikan pelatihan menunjukkan hasil daya ledak otot tungkai dengan nilai $\mathrm{p}$ lebih besar dari 0,05 (p> 0,05) sehingga antara kelompok I dan kelompok II tidak memiliki perbedaan makna. Dapat disimpulkan bahwa hasil daya ledak otot tungkai sebelum diberikan pelatihan antara kedua kelompok tersebut adalah sebanding. Sedangkan pada hasil sesudah diberikan pelatihan antara Kelompok I dengan Kelompok II diketahui memiliki nilai $\mathrm{p}<0,05$, yang berarti bahwa hasil daya ledak otot tungkai antara kedua kelompok tersebut memiliki berbeda makna.

5. Hasil Uji Beda Daya Ledak Otot Tungkai Antara Sebelum dan Sesudah Pelatihan pada Masing-Masing Kelompok

Uji $\mathrm{t}$ berpasangan dimaksudkan untuk melihat perbedaan hasil rerata dari daya ledak otot tungkai sebelum maupun sesudah diberikan pelatihan pada tiap-tiap kelompok dengan nilai yang digunakan $\alpha=$ 0,05 .

Tabel 5

Hasil Uji Beda Rerata Daya Ledak Otot Tungkai Antara Sebelum dan Sesudah Pelatihan

\begin{tabular}{|c|c|c|c|c|c|}
\hline \multirow[b]{2}{*}{ Pelatihan } & \multicolumn{3}{|c|}{ Rerata Hasil Daya Ledak Otot Tungkai (cm) } & \multirow[b]{2}{*}{$\mathrm{t}$} & \multirow[b]{2}{*}{$\mathrm{p}$} \\
\hline & $\begin{array}{c}\text { Sebelum } \\
\text { Pelatihan } \\
\text { Rerata } \pm \mathrm{SB}\end{array}$ & $\begin{array}{c}\text { Sesudah } \\
\text { Pelatihan } \\
\text { Rerata } \pm \text { SB }\end{array}$ & $\begin{array}{c}\text { Selisih } \\
\text { Rerata } \pm \text { SB }\end{array}$ & & \\
\hline Kelompok I & $42,25 \pm 3,94$ & $51,81 \pm 4,15$ & $9,56 \pm 2,63$ & $-14,53$ & 0,000 \\
\hline Kelompok II & $40,25 \pm 5,14$ & $45,25 \pm 5,07$ & $4,88 \pm 1,78$ & $-10,92$ & 0,000 \\
\hline
\end{tabular}

Berdasarkan hasil rerata daya ledak otot tungkai antara sebelum maupun sesudah diberikan pelatihan pada Kelompok I dan Kelompok II memiliki nilai $\mathrm{p}$ lebih $\mathrm{p}<0,05$ yang berarti pada Kelompok I dan Kelompok II terdapat peningkatan secara bermakna antara hasil daya ledak otot tungkai sebelum dan sesudah diberikan pelatihan. Dengan demikian pelatihan pliometrik depth jump dan pliometrik box jump berpengaruh signifikan terhadap peningkatan hasil daya ledak otot tungkai.

\section{PEMBAHASAN}

\section{Pengaruh Pelatihan Pliometrik Depth Jump Terhadap Peningkatan Daya Ledak Otot Tungkai}

Hasil analisis data daya ledak otot tungkai antara pre test dan post test yang dilakukan pada Kelompok I memiliki hasil rerata daya ledak otot tungkai dengan menggunakan uji-t berpasangan atau $t$ paired test diperoleh nilai $\mathrm{p}=0,00$. Dengan demikian daya ledak otot tungkai antara sebelum dan sesudah diberikan pelatihan pada Kelompok I memiliki nilai $\mathrm{p}<0,05$. Berdasarkan hasil tersebut, dapat diketahui terdapat perbedaan yang bermakna, apabila dilihat secara statistik tipe pelatihan tersebut memiliki pengaruh yang signifikan terhadap peningkatan hasil daya ledak otot tungkai. 
Daya ledak otot tungkai meningkat pada kelompok I diakibatkan karena diberikan pelatihan pliometrik depth jump yang brtujuan untuk untuk melatih daya eksflosif dan kecepan reaksi otot. Pelatihan pliometrik depth jump dilakukan dengan cara melangkah dari box yang tingginya dihitung dari hasil rerata tes awal kemampuan melompat (tes vertikal jump menggunakan Jump MD), setelah menyentuh tanah melakukan lompatan setinggi mungkin dengan waktu secepat mungkin di tanah. Pada pelatihan depth jump melibatkan otot tungkai atas, tungkai bawah dan otot lengan yaitu: quadriceps femoris, abductors, adductors, gluteus, hamstrings, calves, deltoideus, pectoralis major, lactisimus dorsi, halucis, biceps dan triceps.

Pelatihan dilakukan sebanyak tiga kali seminggu dan dilaksanakan selama enam minggu dengan beban progresif. Tiga minggu pertama atau sembilan kali pelatihan diberikan beban 6 repetisi 4 set dan tiga minggu berikutnya atau sembilan kali diberikan beban 8 repetisi 4 set. $\mathrm{Nala}^{1}$ mendefinisikan bahwa pelatihan yang dilakukan sesuai dengan dosis atau takaran yang benar akan dapat di adaptasi oleh tubuh selama enam sampai delapan minggu dan apabila pelatihan yang diberikan secara berkelanjutan dan meningkat akan berdampak pada fungsi dari sistem organ tubuh sehingga performa fisik akan menjadi optimal. Untuk menghasilkan peningkatan yang berarti bagi pemula dapat dilakukan dengan frekuensi tiga kali seminggu.

Hipertropi otot disebabkan oleh pelatihan fisik yang dilakukan secara teratur, dimana hipertropi otot dikarenakan keadaan kepadatan pembuluh darah kapiler, jumlah myofibril, saraf, ligament, tendon, serta jumlah kontraktil terutama protein kontaraktil miosin yang meningkat secara proposional. $^{7}$ Semakin sering dilakukan pelatihan maka semakin baik pula pembesaran fibril otot yang menyebabkan adanya peningkatan kekuatan otot ${ }^{8}$. Pada tingkat yang sama, serabut otot tidak terjadi perubahan fiiologis, namun peningkatan yang lebih besar dapat terjadi pada serabut otot putih (fast twitch) yang dapat meningkatkan kecepatan otot. Dengan adanya peningkatan kecepatan serta ditambahkan dengan kekuatan dapat menghasilkan daya ledak otot yang maksimal.

Fokus gerakan pada penelitian ini adalah pada alat gerak tubuh bagian bawah (tungkai bawah dan atas, lengan atas serta kaki) dan juga gerakan yang dilakukan pada lengan. Gerakan yang dilakukan secara berulang-ulang pada penelitian ini dapat menimbulkan kecepatan dan kekuatan serta daya ledak otot yang meningkat dari kondisi awal sebelum dilakukannya pelatihan apabila dilakukan pelatihan secara fisiologis. Peningkatan tersebut juga mempengaruhi hasil loncatan pemain sehingga memudahkan penempatan bola pada saat melakukan teknik smash, jump serve, dan block dalam permainan bola voli.

\section{Pengaruh Pelatihan Pliometrik Box Jump Terhadap Peningkatan Daya Ledak Otot Tungkai}

Dapat diketahui dari hasil tes daya ledak otot tungkai pada tes awal (pre test) dan tes akhir (post test) didapatkan rerata hasil daya ledak otot tungkai sebelum diberikan pelatihan pada Kelompok II (pelatihan pliometrik box jump) adalah $40,25 \mathrm{~cm} \pm 5,14$ dan sesudah diberikan pelatihan $45,25 \mathrm{~cm} \pm 5,07$. Peningkatan yang terjadi terhadap hasil daya ledak otot tungkai antara sebelum dan sesudah diberikan pelatihan pada Kelompok II sebesar 4,88 $\pm 1,78 \mathrm{~cm}$.

Dari analisis data hasil daya ledak otot tungkai antara pre test dan post test yang dilakukan pada Kelompok II 
menggunakan uji t-paired test didapatkan bahwa hasil $\mathrm{p}=0,00$ yang berarti nilai tersebut memiliki $\mathrm{p}$ lebih kecil dari 0,05 $(\mathrm{p}<0,05)$. Sehingga terdapat perbedaan yang bermakna antara sebelum dan sesudah diberikan pelatihan. Berdasarkan hasil tersebut dapat disimpulkan bahwa tipe pelatihan yang diterapkan secara statistik memiliki pengaruh yang signifikan terhadap peningkatan hasil daya ledak otot tungkai.

Peningkatan daya ledak otot tungkai terjadi pada Kelompok II diakibatkan karena diberikan pelatihan pliometrik box jump yang diawali dengan gerakan meloncat ke depan atas dan mendarat di atas box yang tingginya dihitung dari hasil rerata tes daya ledak otot tungkai (tes vertikal jump menggunakan Jump MD). Pada latihan box jump, otot-otot yang antara lain ekstens lutut, fleksi paha, addukasi dan abdukasi yang melibatkan otot quadriceps femoris, gluteus, abdukteor longus, brevis, magnus minimus dan halucis.

Pelatihan dilakukan sebanyak tiga kali seminggu dan dilaksanakan selama enam minggu dengan beban progresif. Tiga minggu pertama atau sembilan kali pelatihan diberikan beban 6 repetisi 4 set dan tiga minggu berikutnya atau sembilan kali diberikan beban 8 repetisi 4 set. Menurut Nala. ${ }^{1}$ pelatihan yang diberikan secara teratur dalam kurun waktu enam sampai delapan minggu akan dapat memberikan hasil yang nyata, ini disebabkan oleh tubuh sudah mampu adaptasi dengan kondisi pelatihan yang diberikan. Nala juga beranggapan bahwa optimalnya panampilan fisik pemain dipengaruhi oleh pelatihan yang dilaksanakan secara berulang-ulang, progresif dan sistematis dari pelatihan tersebut mengakibatkan perbaikan sistem organ tubuh pemain. Untuk menghasilkan peningkatan penampilan pemain maka perlu dilakukan pelatihan bagi para pemula dengan frekuensi tiga kali dalam seminggu.
Terjadinya hipertropi fisiologi otot disebabkan oleh karena pelatihan yang dilakukan secara teratur. Hipertropi fisiologi otot dipengaruhi oleh jumlah myofibril, kepadatan pembuluh kapiler, saraf, tendon dan ligament, dan jumlah kontraktil terutama protein kontaraktil miosin yang meningkat secara proposional. ${ }^{7}$ Semakin sering dilakukan pelatihan maka pembesaran fibril otot akan semakin baik sehingga terjadi peningkatan kekuatan otot. ${ }^{8}$

Terdapat dua komponen pokok yang mempengaruhi daya ledak diantara komponen biomotorik yaitu kecepatan dan kekuatan yang dapat apabila dilakukan saat pelatihan mampu meningkatkan daya ledak. Pelatihan beban yaitu pelatihan yang dilakukan secara terorganisir dimana otototot tubuh berkontraksi. Reaksi tersebut sebagai respon terhadap beban eksternal, tahanan tubuh atau peralatan lain yang digunakan untuk menstimulasi kekuatan dan pertumbuhan merupakan pelatihan beban. $^{9}$ Otot-otot yang melekat dan membungkus tungkai mempengaruhi besar kecilnya daya ledak. Sedangkan terjadinya gerakan pada tungkai tersebut disebabkan oleh adanya otot-otot dan tulang dimana otot sebagai alat gerak aktif dan tulang sebagai alat gerak pasif. ${ }^{10}$ Komponen penting dalam menentukan tinggi loncatan yaitu dipengaruhi oleh daya ledak otot tungkai dimana besarnya power tungkai pada otot tungkai mengakibatkan seorang atlet mampu mencapai nilai power tertentu dengan mengatasi beban atau tahanan guna pada sudut tertentu. ${ }^{11}$

\section{Perbedaan Pengaruh Pelatihan Pliometrik Depth Jump dan Box Jump Terhadap Peningkatan Daya Ledak Otot Tungkai}

Perbedaan hasil yang terjadi disebabkan oleh perbedaan jenis gerakan yang diberikan selama pelatihan. Perbedaan 
beban terhadap tubuh selama diberi pelatihan menyebabkan respon fisiologis tubuh mampu beradaptasi dengan pelatihan yang diberikan dimana terjadi regangan otot yang berulang sehingga dapat menyebabkan daya dorong atau kontraksi gerakan yang semakin besar ${ }^{2}$. Dilihat dari perbedaan gerakan pada pelatihan depth jump yang dimana pelatihan tersebut ditujukan untuk mengembangkan daya ledak eksflosif dan kecepatan reaksi, yang diawali melangkah dari box, setelah di tanah harus melakukan lompatan maksimal dengan waktu yang singkat. Sedangkan pada pelatihan pliometrik box jump diawali dengan gerakan meloncat ke depan atas dan mendarat di atas box. Pengulangan gerakan lebih pada pelatihan depth jump banyak dibandingkan dengan pelatihan box jump sehingga menyebabkan beban pada otot lebih besar. Penampilan fisik yang optimal dapat disebabkan oleh pelatihan yang diberikan secara sistematis, berulang-ulang dan progresif sehingga mampu memperbaiki sistem organ tubuh. ${ }^{12}$ Apabila latihan fisik dapat dilakukan secara teratur akan menyebabkan hipertropi pada otot, hal tersebut dapat terjadi dikarenakan beberapa hal seperti: jumlah myofibril, saraf, kepadatan pembuluh darah kapiler, tendon, ligamen dan jumlah kontraktil terutama protein kontaraktil miosin yang meningkat secara proporsional. Apabila pelatihan yang dilakukan semakin sering maka semakin baik pula pembesaran fibril otot, sehingga mampu meningkatkan kekuatan otot. ${ }^{8}$ Pada tingkatan yang sama tidak akan terjadi perubahan fisiologis pada serabut otot, namun peningkatan yang lebih besar terjadi pada serabut otot putih (fast twitch) sehingga dapat mengakibatkan peningkatan pada kecepatan otot. Daya ledak otot yang maksimal dikarenakan peningkatan kecepatan dan ditambah dengan kekuatan.
Perbedaan jenis gerakan yang diberikan memberikan respon yang berbeda pula dari subjek, sehingga memiliki pengaruh yang berbeda terhadap pembentukan kemampuan pada subjek yang diberikan pelatihan. ${ }^{13}$ Maka dari itu, kelompok yang diberikan pelatihan pliometrik box jump dan pelatihan pliometrik depth jump memiliki pengaruh yang berbeda terhadap peningkatan pada kemampuan daya ledak otot tungkai, walau repetisi dan set dalam pelatihan sudah dibuat sama.

\section{SIMPULAN}

Bersadarkan uraian dan hasil penelitian yang telah dilakukan, dapat disimpulkan bahwa :

1. Pelatihan pliometrik depth jump meningkatkan daya ledak otot tungkai sebesar $9,56 \mathrm{~cm}$ atau $22,63 \%$ pada siswa peserta ekstrakurikuler bola voli SMK Negeri 1 Petang.

2. Pelatihan pliometrik box jump meningkatkan daya ledak otot tungkai sebesar $4,88 \mathrm{~cm}$ atau $12,07 \%$ pada siswa peserta ekstrakurikuler bola voli SMK Negeri 1 Petang.

3. Pelatihan pliometrik depth jump lebih meningkatkan daya ledak otot tungkai daripada pelatihan pliometrik box jump siswa peserta ekstrakurikuler bola voli SMK Negeri 1 Petang.

\section{DAFTAR PUSTAKA}

1. Nala, N. 2011. Prinsip Pelatihan Fisik Olahraga. Denpasar: Komite Olahraga Udayana University Press.

2. Sajoto. 2002. Peningkatan dan pembinaan Kekuatan Kondisi Fisik. Semarang: Effar dan Dahara Prize. P. 70

3. Yunus. 2000. Pedoman dan modul pelatihan kesehatan olahraga bagi pelatih olahraga pelajar. Jakarta: 
Depdiknas pusat pelayanan pendidikan jasmani.

4. Fadiel. 2011. Analisis Biomekanika Bola Voli. (serial online) Juli.[cited 2015 Jan 15].Available from http://fadielkumooon.blogspot.com/2011 /07/analisis-biomekanika-bola voli.html.

5. Laksana, I M. K. 2015. Pelatihan Melompati Rintangan Setinggi $60 \mathrm{~cm}$ Lebih Baik Dibandingkan Rintangan Setinggi $30 \mathrm{~cm}$ Untuk Meningkatkan Ketepatan Jumping Smash Pemain Bulutangkis SMK Negeri 2 Kuripan Lombok Barat. Denpasar: ISSN:2302688X. Sport and Fitness Journal Volume 4, No. $1: 37-58$.

6. Radcliffe, J. C \& Farentinos, R.C. 2002. Plyometrics Explosive Power Training. 3rd ed. Champaign, Illionis: Human kinetics Published, Inc.

7. Prananta, C. A. 2014. "Perbandingan Jump Shoot Dengan Awalan dan Tanpa Awalan Terhadap Peningkatan Ketepatan Jump Shooting Dalam Permainan Bola Basket" Denpasar: ISSN:2302-688X. Sport and Fitness Journal Volume 3, No.1 : 8-25.

8. Sudarsono, S. 2011. Penyusunan Program Pelatihan Berbeban untuk Meningkatkan Kekuatan. Jurnal Ilmiah SPIRIT, ISSN:1411-8319 No 3

9. Tangkas, D. Pengaruh Pelatihan Plaiometrik Terhadap Kemampuan
Lompat Jauh Gaya Jongkok Ditinjau Dari Daya Ledak Otot Tungkai Pada Siswa Kelas X SMA Negeri 1 Sukasada Tahun Pelajaran 2013/2014. Singaraja: e-Journal Program Pascasarjana Penelitian dan Evaluasi Pendidikan, Volume:4 Tahun 2014.

10. Rogers, P. 2009. Basic strength and muscle weight training program. Aviable Form: http//weihtraening.abaut.com

11. Widiantari, Sutjana I. D.P dan Adiatmika I. P. G. 2015. Perbandingan Pelatihan Loncat Rintangan 50CM Dengan Variasi Lari Cepat 5 Meter Antara 10 Repetisi 3 Set dan 5 repetisi 6 Set Terhadap Peningkatan Tinggi Loncatan Vertikal Pada Mahasiswa Semester II Putra di FPOK IKIP PGRI Bali. Denpasar. ISSN:2302-688X. Sport and Fitness Journal Volume 3, No.2 : 67-78.

12. Huawe, J.2017. Pelatihan Loncat Tegak Tanpa Awalan Lebih Meningkatkan Daya Ledak Otot Tungkai Daripada Pelatihan Lompat Bergantian Denpasar. ISSN: 2302-688X Sport and Fitness Journal Volume 5, No.2 : 114-123.

13. Darma, D. 2017. Pelatihan Plyometric Broad Jump Lebih Meningkatkan Kemampuan Lompat Jauh Dari Pada Pelatihan Plyometric Box Jump. Denpasar. ISSN: 2302-688X Sport and Fitness Journal Volume 4, No.1 : 3 